\title{
Land-Use Change, Economics, and Rural Well-Being in the Prairie Pothole Region of the United States
}

\section{Purpose}

This fact sheet highlights findings included in a comprehensive new report which investigated land-use change, economic characteristics, and rural community well-being in the Prairie Pothole Region of the United States. Please refer to the end of this fact sheet for information on accessing the full report or individual chapters.

\section{Background}

The Prairie Pothole Region (PPR), encompassing most of the Northern Great Plains, once was one of the largest grasslandwetland ecosystems on earth. The ecological makeup of the region provides essential habitat for an array of wildlife, most notably migratory waterfowl. The ecosystem also provides necessary inputs for agricultural production, which has become the dominant land use over the last century. Both perennial habitat lands and agricultural lands retain importance economically, socially, and culturally. New land-use dynamics have come into play with expansion of oil and gas production. The economic influences of production land uses, such as agriculture and energy development, typically are better understood than is the influence of lands in conserved natural habitat. Nonetheless, perennial habitat lands certainly have environmental and economic influence, along with linkages to various aspects of rural community well-being. Research reported here focuses on those land-use dynamics and attempts to illuminate how economic variables and rural development in the PPR might be influenced as land uses change. Policy makers and land managers constantly are faced with decisions regarding land use, and they need information regarding the impacts of their decisions.

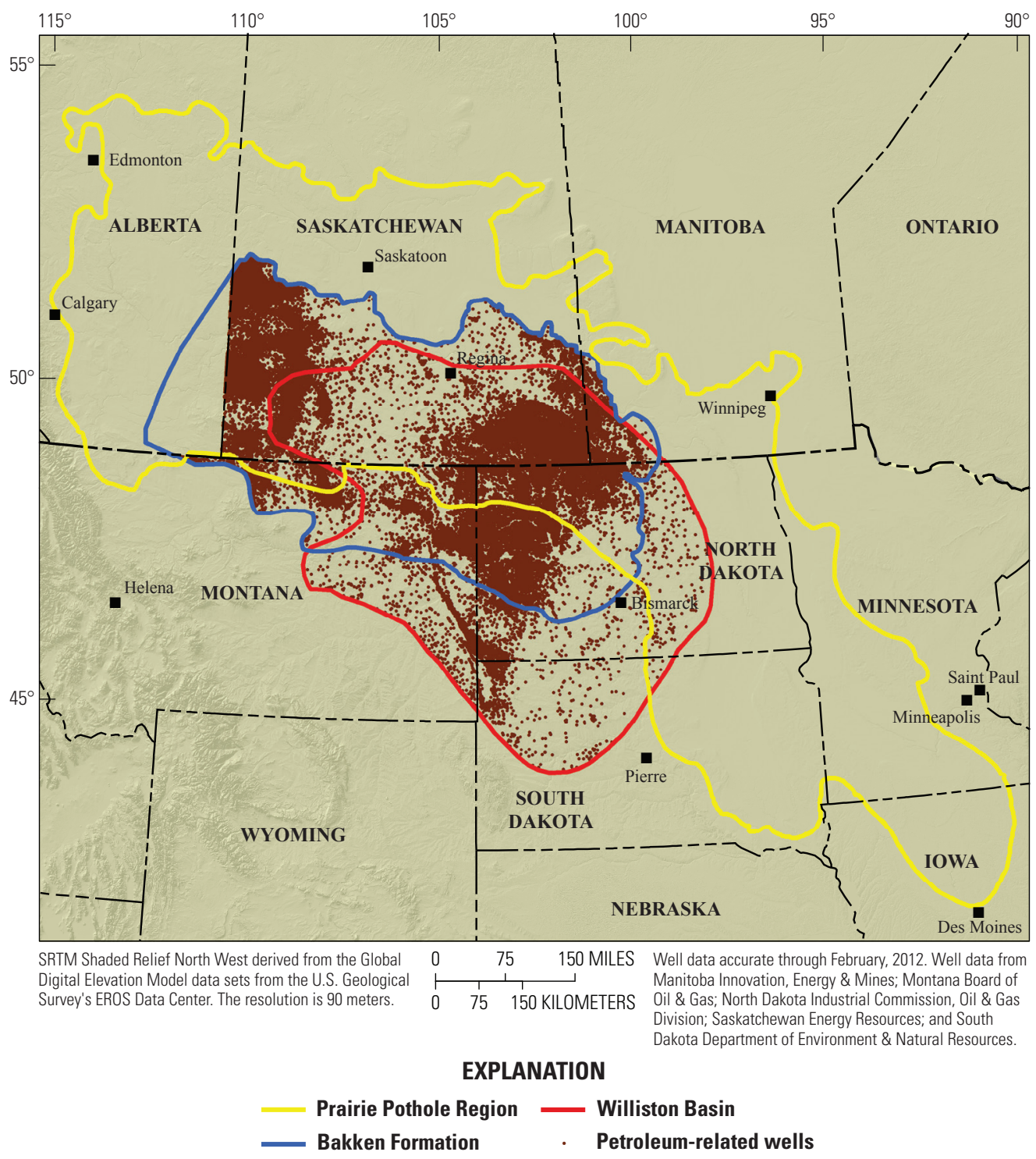

Figure 1. Map of the extent of the Bakken Formation and of the Williston Basin in the Prairie Pothole Region of the United States and Canada. Brown points represent the spatial distribution of petroleum wells in the region as of February 2012. Data compiled and merged by Tara Chesley-Preston, U.S. Geological Survey. Spatial well data were unavailable for the province of Alberta. 


\section{Evolution of Land Use in the Prairie Pothole Region}

- A vast amount of land in the PPR remains in farming. The amount of cropland used for crops has remained relatively constant or has decreased only minimally in the last half century, currently totaling around 85 million acres.

- Farm consolidation has taken place in the region. As the overall number of farms has decreased, the average size of farms has increased. Over the last 50 years, average farm size has increased between 57-74 percent among PPR states.

- Crop mix continues to evolve, with record-high plantings of corn and soybeans. In the 10-year period from 1997-2007, the amount of land planted to corn increased by nearly 300 percent in North Dakota. From 2005-2007 alone, more than 3.2 million acres were converted to corn across PPR regions of Iowa, Minnesota, North Dakota, and South Dakota.

- Oil and gas production has soared to new heights. North Dakota recently surpassed Alaska as the number 2 oil producer in the nation, trailing only Texas in terms of oil volume. At the end of 2012, there were over 8,200 active oil wells in North Dakota.

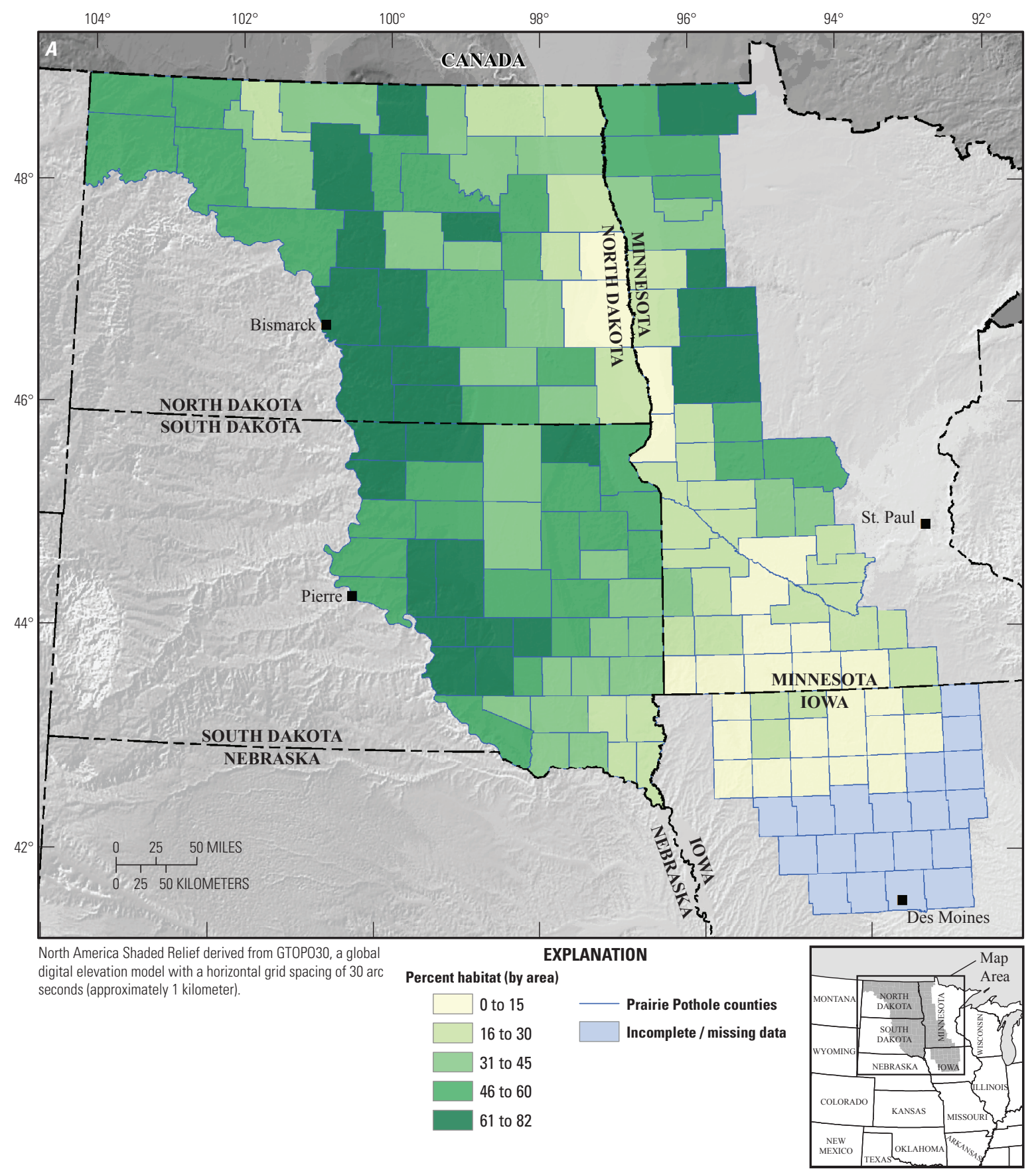

Figure 2A. Percentage of county acres classified as perennial habitat in the Prairie Pothole Region of the United States, based on 2006 U.S. Fish and Wildlife Service, Habitat and Population Evaluation Team (HAPET) land-cover data (Fry and others, 2011). 
Based on land area, well-development assumptions, and various risk factors, industry experts predict the number of wells for complete North Dakota Bakken well development to be around 39,000, which would make the North Dakota portion of the Bakken Formation the largest oil field in U.S. history (Mason, 2012). Figure 1 shows the spatial distribution of petroleum wells in the Bakken Formation and the Williston Basin since 1925 through 2012.

- Current distribution of perennial habitat varies by county. As shown in figure 2A, some counties have very little remaining perennial habitat, while other counties still retain large proportions of habitat lands. The percentage of lands protected in either short- (such as the Conservation Reserve Program) or long-term (perpetual easements) contracts ranges from 1-40 percent of total county acreage (fig. 2B).

- Lands enrolled in the Conservation Reserve Program (CRP) have a large influence on perennial habitat calculations. The acres in the CRP stand to alter the distribution of habitat in coming years given the uncertain future and timing of expiring contracts in the program. After peaking in 2007, CRP acres in the PPR have declined by more than 1 million acres (roughly 18 percent), with 2010 enrollment at just more than 4.8 million acres.

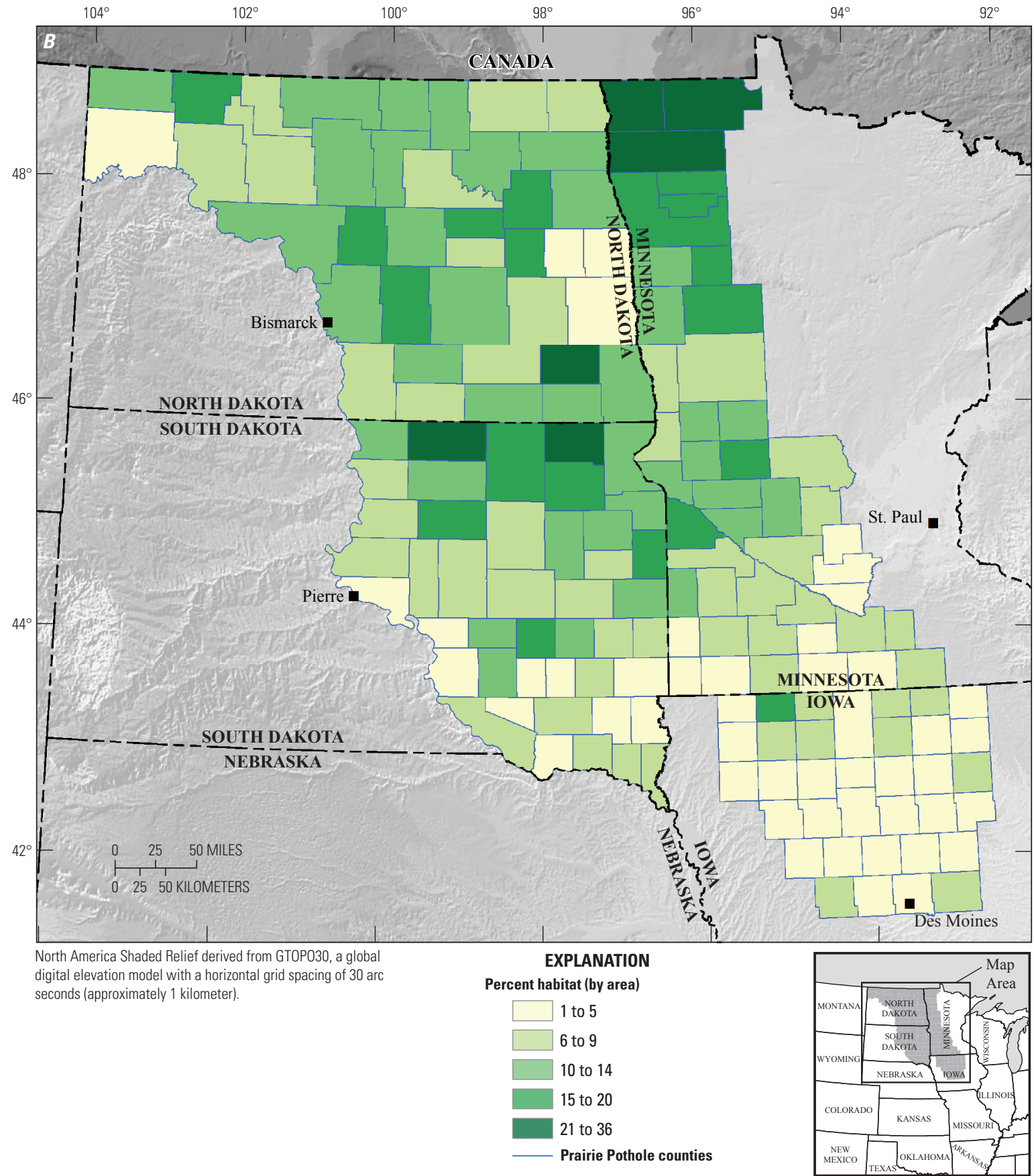

Figure 2B. Perennial habitat as defined by lands with a protected (short- and long-term) status, conserved status, and managed for wildlife-friendly cover in the Prairie Pothole Region of the United States, shown as percentage of total county acres. Multiple sources used for data compilation; please refer to Appendix B of Professional Paper for complete list. 


\section{The Farm and Non-Farm Economies}

- Many PPR counties still are considered farming-dependent. Farming-dependent counties are those in which farm employment constitutes 15 percent or more of total employment. Sheridan County and Kidder County in North Dakota exhibit the highest percentages. At the regional level, farm employment has a much smaller footprint. About 40 years ago, farm employment was more than 18 percent of the entire workforce in the PPR. Today it accounts for only just over 6 percent, reflecting a 66-percent drop (fig. 3). Out of 45 PPR counties in Minnesota, only 15 (33 percent) are farm-dependent. Likewise, only 8 of the 35 counties ( 23 percent) in the PPR portion of Iowa are farm-dependent.

- Declining farm employment in the PPR largely is a result of changes in farming itself (for example, technical advances). Outside stressors such as competing land uses have less impact on farm employment than do changes in farming technology (Johnson and Rathge, 2006; Irwin and others, 2010).

- Rural areas may experience more spending leakage - dollars leaving the area - as farm size grows. The likelihood of farmers needing to purchase production inputs from outside the local region increases as farms become larger, more complex, and more specialized (Marousek, 1979; Harris and others, 2008).

- The health of the farm economy has become much more dependent on the health of the off-farm economy. Findings indicate it is difficult to support agriculture in a region without investing in the off-farm economy at the same time.

A weak off-farm economy in an area experiencing farm consolidation is likely to lead to continuous outmigration and to impact negatively any local employment opportunities.

- Perennial habitat provides goods and services that have value to people. Examples include cleaner drinking water, flood regulation, pollinator habitat, and habitat suitability for important game species such as pheasants and waterfowl.

- The combination of jobs in the retail trade, the arts, entertainment and recreation, and accommodation and food services - all sectors that reflect the tourism industry - make up more than 18 percent of the total private labor force in the multi-state PPR. In North Dakota alone, the tourism industry in 2010 contributed $\$ 4.62$ billion to the state economy. Tourism ranks third among industries, and much of the tourism in North Dakota is based on natural amenities and wildlife populations.

- Expenditures on hunting and wildlife viewing contribute jobs and income in the region. Conservatively modeled, hunting and wildlife viewing in the PPR are estimated to be contributing close to 10,000 jobs, $\$ 760$ million in labor income, and $\$ 450$ million in value added to the regional economy.

- Restoration of perennial habitat can have positive economic impacts. We estimate the operational dollars (that is, excluding spending by visitors) of the U.S. Fish and Wildlife Service National Refuge System and the Partners for Fish and Wildlife Program spent in the PPR are supporting close to 900 jobs, $\$ 40$ million in labor income, and $\$ 50$ million in value added in the region.

Photo credit: Justin Goetz.

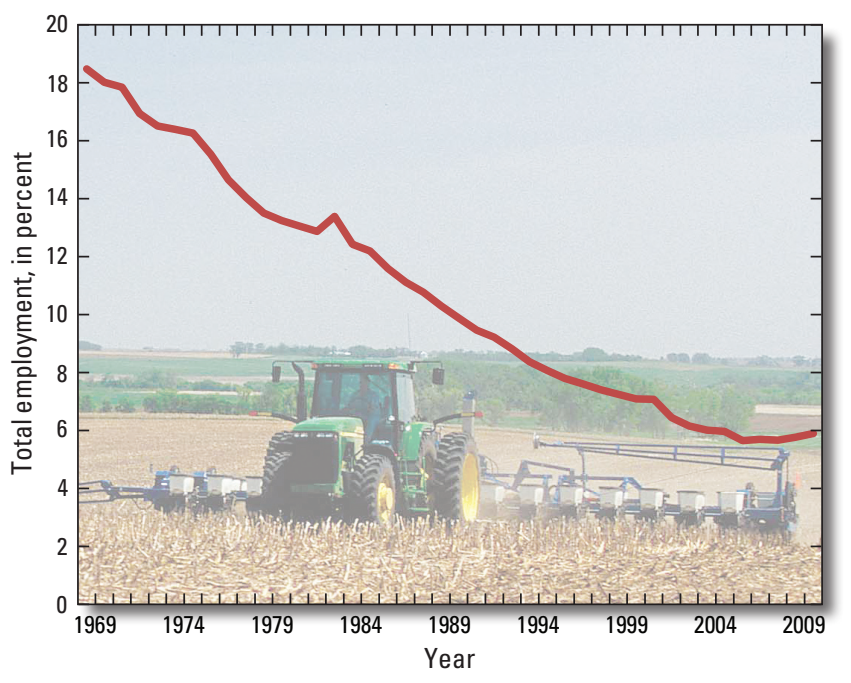

Figure 3. Farm employment by year as a percentage of total employment for the Prairie Pothole Region of the United States, 1969-2010. Modified from data from the U.S. Department of Commerce, Bureau of Economic Analysis (2010). (Photo: Don Poggensee of the U.S. Department of Agriculture, Natural Resources Conservation Service.)

\section{Rural Development and Well-Being}

- Each community in the PPR is unique, and land-use decisions will have varying effects. For instance, the impact of removing agricultural land from production will depend on the economic makeup of the local region, its transportation infrastructure, the number of implement dealers, the number of absentee landowners, and other socioeconomic factors.

- High levels of economic dependence on agriculture could hinder economic growth. Previous research findings indicate that higher dependency on production agriculture, either overall dependence or a larger proportion of large farms, reduces growth rates and hinders the ability of the rural U.S. to grow at faster rates (Deller et al. 2005; Monchuk and others, 2005).

- Conserved/protected habitat can have a positive influence on job and income growth. Each community is unique. There is, however, an extensive and growing body of literature that indicates natural amenities are related positively with economic growth variables.

- Outmigration continues to be a problem for many rural communities in the Prairie Pothole Region (fig. 4). A suite of factors contributes to this trend, some of which are tied strongly to landscape conditions.

- Migration patterns are influenced heavily by the level of natural amenities and recreational opportunities in an area. Our research discovered a host of qualitative and quantitative findings supporting this statement. This relationship especially is true when considering younger generations entering or looking to enter the workforce.

- Jobs follow people just as much as people follow jobs. That is, attract people to an area, and job opportunities will follow as local demand for goods and services increases. 
- Local stakeholders routinely report that they seek a rural way of life. Respondents referred to the pace of life, open landscapes, outdoor recreational opportunities, sense of community, and agricultural traditions as important factors.

- Quantitative growth (that is, jobs and income) is not necessarily better. Recent experiences in northwestern North Dakota corresponding to the oil and gas boom provide abundant evidence. While employment and income are on the rise, so too are crime rates, road congestion, and the cost of living. These trends show that the overall effect of quantitative growth on well-being is, at best, ambiguous. It has been stated that to unambiguously serve the public interest, local rural development policies must raise living standards, including both pay and the quantity and quality of local amenities.

- It is important to consider long-term health when devoting resources to short-term growth. It is fine to have short-term strategies geared towards specialized growth. The key for long-term health, however, is to have diversity within those strategies.

- Municipal revenue from preserved lands is extremely important to county commissioners. Refuge Revenue Sharing Payments - money paid to municipalities by the U.S. Fish and Wildlife Service in lieu of property taxes - have been declining steadily. However, conserved open lands typically require fewer municipal services.

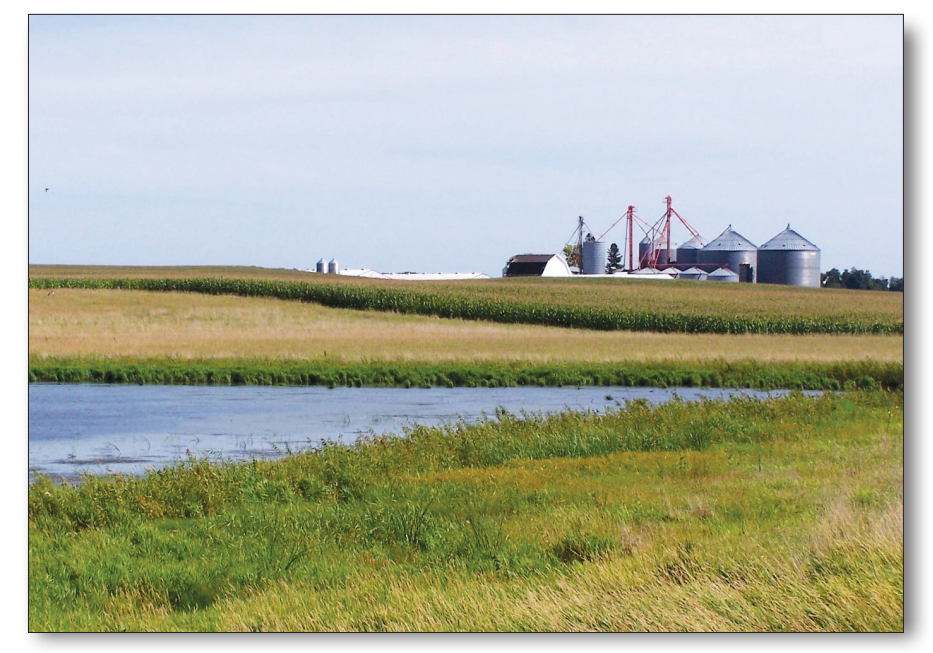

Photograph of farmland with wetland buffered by acres enrolled in the Conservation Reserve Program, Prairie Potholes Region, lowa. Photograph by Mark Vandever, U.S. Geological Survey, 2004.

\section{Concluding Remarks on the Health of the Prairie Pothole Region Economy}

Agriculture has long been the economic engine of the Prairie Pothole Region and remains important not only economically, but also socially and culturally. Our study, however, reveals that the health of the agricultural community in the PPR currently is interconnected in a number of ways to the

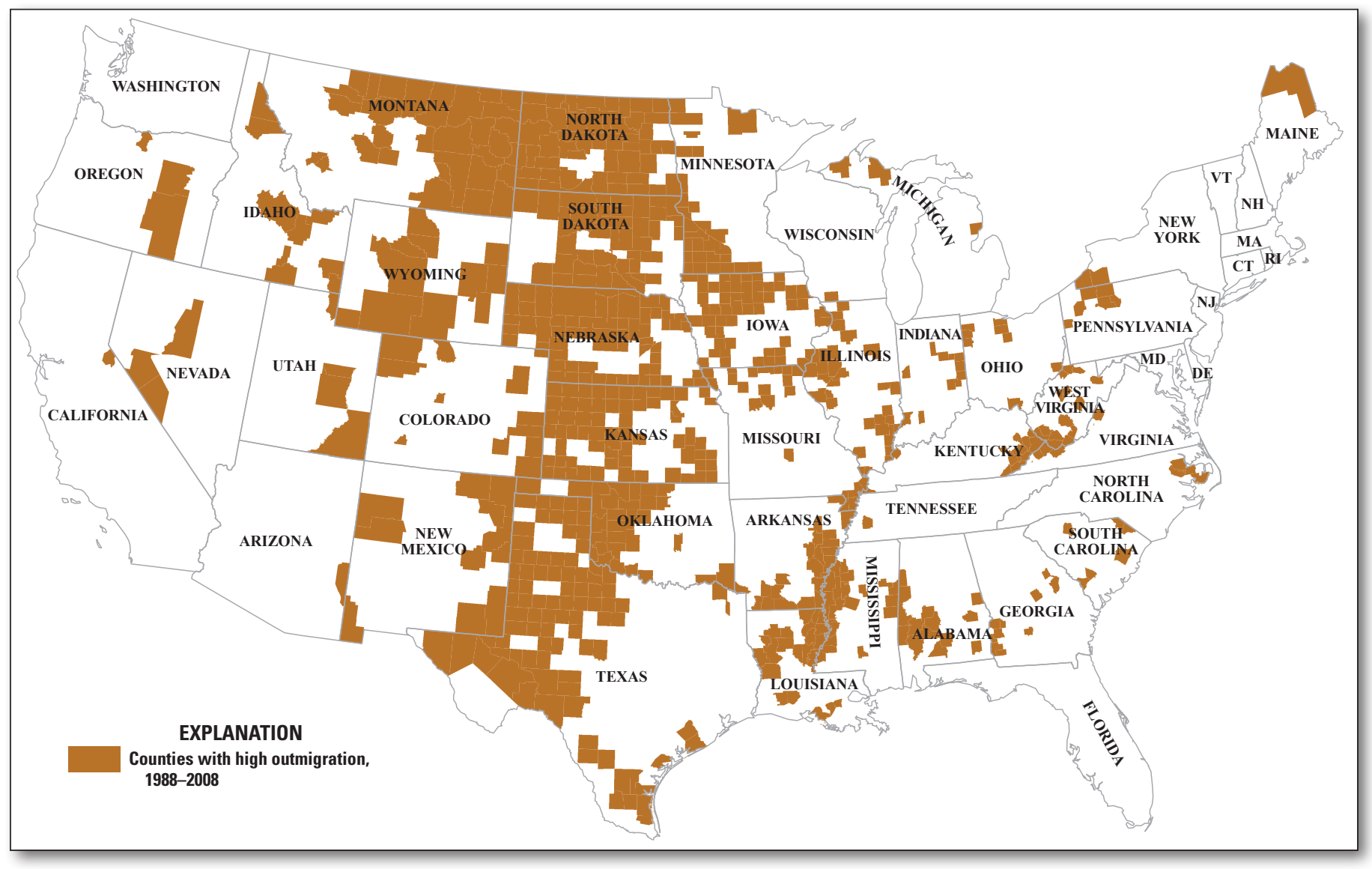

Figure 4. United States counties with the highest outmigration levels from 1998-2008. A county is classified as high outmigration if it had 10 percent or higher population loss from net migration. Data modified from the Atlas of Rural and Small-town America, U.S. Department of Agriculture, Economic Research Service (2011). (Abbreviations here include United States mail-code state abbreviations). 
rural nonfarm economy, possibly more than ever. It was once believed that a strong off-farm economy was dependent on a strong farm economy. Now, research has shown that a strong farm economy and the persistence of family farms are just as, if not more so, dependent on a strong off-farm economy and labor market. These findings indicate that investment of time and resources in strengthening the nonfarm rural economy may greatly assist local governing officials as they work to support agriculture in the community. The off-farm economy is powered by the demand for additional goods and services. At a local scale, this involves spending from local residents and from outsiders attracted to the area. In order to sustain or increase such demand, local officials must take into consideration their area's endowment and the reasons people enjoy living in or visiting the area. It is well-documented that people choose to live in an area based both on economic opportunity and area amenities such as schools and other public services, environmental conditions, landscape aesthetics, and outdoor recreational opportunities. The tourism industry in North and South Dakota ranks third and second, respectively, growing at above the national average in both states and heavily based on outdoor experiences and wildlife recreation. Policymakers who think holistically about land-use change will understand the linkages between their decisions and aspects of community well-being. Such decisions will be extremely influential not only on the landscape of the region and the wildlife that inhabit it, but also the demographic, economic, and cultural makeup of the PPR.

\section{The full report has been published as a USGS Professional Paper. The full report is made up of three individual chapters, organized as follows:}

Chapter 1: Land-Use Dynamics in the Prairie Pothole Region Chapter 2: The Prairie Pothole Region Economy and Economic Linkages to the Landscape

Chapter 3: Land Use and Rural Development

Executive Summary-Lessons Learned and the Future of

Conservation in the Prairie Pothole Region

http://pubs.usgs.gov/pp/1800/

\section{To download and view the full report with complete literature citations, or any of the individual chapters, please go to:}

http://www.plainsandprairiepotholeslcc.org/

\section{Project Principal Investigators}

William Gascoigne, U.S. Geological Survey, Fort Collins Science Center, Fort Collins, Colorado

Dana L.K. Hoag, Department of Agricultural and Resource Economics, Colorado State University, Fort Collins, Colorado

Rex Johnson, U.S. Fish and Wildlife Service, Habitat and Population Evaluation Team, Fergus Falls, Minnesota

Lynne Koontz, U.S. Geological Survey, Fort Collins Science Center, Fort Collins, Colorado

Catherine Cullinane Thomas, U.S. Geological Survey, Fort Collins Science Center, Fort Collins, Colorado

\section{For more information, contact}

William Gascoigne, USGS Fort Collins Science Center, 2150 Centre Ave., Bldg. C, Fort Collins, CO 80526 Phone: 970-226-9227 E-mail: gascoignew@usgs.gov

\section{Selected References}

Deller, S.C., Marcouiller, D.W., English, D.B.K., and Lledo, V., 2005, Regional economic growth with a focus on amenities, in Green, G.P., Deller, S.C., and Marcouiller, D.W., eds., Amenities and rural development-Theory, methods, and public policy: Cheltenham, U.K., and Northampton, Mass., Elgar Publishing, New Horizons in Environmental Economics series, p. 129-152.

Fry, J.A., Xian, George, Jin, Suming, Dewitz, J.A., Homer, C.G., Yang, Limin, Barnes, C.A., Herold, N.D., and Wickham, J.D., 2011, Completion of the 2006 National Land Cover Database for the conterminous United States: Photogrammetric Engineering and Remote Sensing, v. 77, no. 9, p. 858-864.

Harris, J.M., Erickson, K., Dillard, J., Morehart, M., Strickland, R., Gibbs, R., Ahearn, M., Covey, T., Bagi, F., Brown, D., McGath, C., Vogel, S., Williams, B., and Johnson, J., 2008, Agricultural income and finance outlook: U.S. Department of Agriculture, Economic Research Service, Report AIS-86, December 2008, 74 p.

Irwin, E.G., Isserman, A.M., Kilkenny, M., and Partridge, M.D., 2010, A century of research on rural development and regional issues: American Journal of Agricultural Economics, v. 92, no. 2, p. 522-553.

Johnson, K.M., and Rathge, R.W., 2006, Agricultural dependence and changing population in the Great Plains, in Kandel, W.A., and Brown, D.L., eds., Population change and rural society: Dordrecht, The Netherlands, Springer, 197 p.

Marousek, G., 1979, Farm size and rural communities-Some economic relationships: Southern Journal of Agricultural Economics, v. 11, p. 57-61.

Mason, J., 2012, Bakken's maximum potential oil production rate explored: Oil and Gas Journal, published April 2, 2012. Available at http://www.ogj.com, accessed February 2012.

Monchuk, D.C., Miranowski, J.A., Hayes, D.J. and Babcock, B.A., 2005, An analysis of regional economic growth in the U.S. Midwest: Review of Agricultural Economics,

v. 29 , no. 1 , p. $17-39$.

U.S. Department of Agriculture Economic Research Service [USDA-ERS], 2011, Atlas of rural and small-town AmericaJobs, unemployment rate, outmigration patterns: Washington, D.C., U.S. Department of Agriculture Economic Research Service. Available at http://www.ers.usda.gov/data-products/atlasof-rural-and-small-town-america.aspx, accessed April 3, 2012.

U.S. Department of Commerce Bureau of Economic Analysis [USDC-BEA], 2010, Annual state and local area personal income and employment—Regional data: Washington, D.C., U.S. Department of Commerce Bureau of Economic Analysis, unpaginated. Available at http://www.bea.gov/regional/, accessed May 20, 2013.

Photograph of rancher and son assessing cattle herd grazing the rolling prairie grasslands, Prairie Pothole Region, South Dakota. Photograph by Tim McCabe, United States-Department of Agriculture, Natural Resource Conservationservice, 2011 .

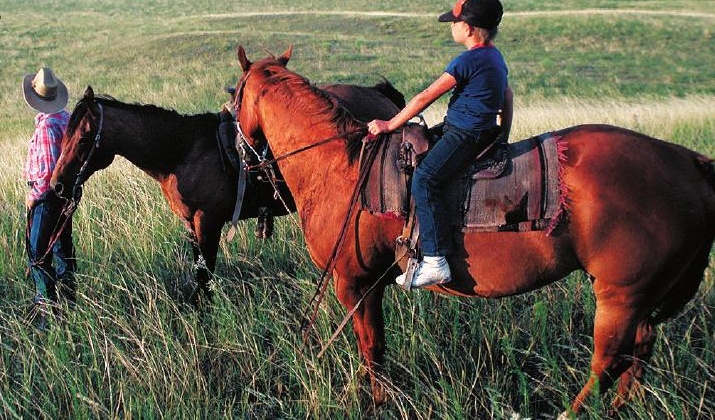

